\title{
A MYOPATHY PRESENTING IN ADULT LIFE WITH FEATURES SUGGESTIVE OF GLYCOGEN STORAGE DISEASE
}

\author{
BY
}

\author{
J. MACDONALD HOLMES, C. R. HOUGHTON, and A. L. WOOLF*
}

From the Midland Centre for Neurosurgery, Smethwick

Following von Gierke's (1929) description of the hepatonephromegalic form of glycogen storage disease, Pompe $(1932,1933)$ and Kimmelstiel (1933) published reports of a cardiomegalic form (see Table I). Kimmelstiel's case was the first in which deposition of glycogen within the cells of the nervous system was noted, and the two cases were the first in which glycogen deposition in skeletal muscle had been mentioned. Neither of these cases showed any clinical evidence of muscular involvement. In 1936, Wolff reported a case in which the muscles were described as poorly developed. In 1939, Günther reported a case of an infant, 11 months old at the time of death, in whom widespread flaccid paralysis was a striking feature. Childs, Crosse, and Henderson (1952) reported a brother and sister who both died within the first two years of life from glycogen storage disease affecting the liver, heart, nervous system, and skeletal muscles, in whom progressive weakness was among the presenting symptoms. Krivit, Polglase, Gunn, and Tyler (1953) described two further similar cases. More recently Zellweger (1956) and Zellweger, Dark, and Abu Haidar (1955) have reported three cases presenting with a clinical picture suggestive of Werdnig-Hoffmann disease in whom a diagnosis of glycogen storage disease was established by chemical estimation of glycogen in biopsy specimens of muscle. Within the last two years Schnabel (1958) has reported a further case of hepato - cardio-neuromuscular glycogen storage disease in which the patient at $5 \frac{1}{2}$ months of age showed scarcely any active movement. No case of glycogen storage disease has ever been reported as presenting clinically with symptoms of muscular involvement except in infancy, and although there is on record a single report (Antopol, Boas, Levison, and Tuchman, 1940) in which two brothers aged 11 years and 15 years were shown to have been suffering from the cardiomegalic form of the disease, there was no suggestion of muscular weakness.

*In receipt of a grant from the Muscular Dystrophy Association of America Inc.
Thus the case we are about to report, if due to glycogen storage disease, appears to be unique in that the patient presented at the age of 21 with symptoms of a myopathy and did not die until the age of 31 years. It will be seen that the histological findings differed considerably from those in the infantile cases, and although evidence of the disease was in fact present in repeated muscle biopsies carried out during life, the dramatic lesions were misinterpreted as indicating a parasitic infection and prevented us from undertaking appropriate bio chemical investigations.

We are, therefore, making this report in the hope that subsequent cases may be recognized durin life and appropriate studies made.

\section{Case Report}

Clinical History.-The patient was a young woman aged 31 years who was first seen by one of us in March 1958 , for investigation of weakness of the legs.

She had noticed a difficulty in climbing stairs nine years before and at about the same time found difficulty in rising from a chair. The weakness progressed very slowly and the next symptom was difficulty in rising from a lying position. She noticed that the muscular weakness was worse in very cold or hot weather, but there was no variation throughout the day. In the past three or four years the weakness of the legs had become much worse and the knees would often give way, especially the right.

In 1950, she attended the neurological clinic in another hospital, where myasthenia gravis was suspected, but there was no response to neostigmine. The reason for suspecting myasthenia seems to have been the occasional failure of her voice to a faint whisper, but she said that this had occurred since adolescence and it appears to have been a functional aphonia. She had also had bilateral operations for dacryocystitis in childhood which had produced an appearance of her eyelids suggesting slight ptosis. A later diagnosis made in the same hospital was thyrotoxic myopathy, but at no time was there convincing evidence of thyrotoxicosis.

She was said to have had meningitis at the age of 5 years, but this left no sequelae. In 1954, she had pneumonia and came under observation at a chest clinic. 
TABLE I

SUMMARY OF REPORTED CASES OF GLYCOGEN STORAGE DISEASE AFFECTING MUSCLE

\begin{tabular}{|c|c|c|c|c|c|c|c|}
\hline Author & Date & $\begin{array}{l}\text { Age of } \\
\text { Patient }\end{array}$ & Liver & Heart & Muscles & $\begin{array}{l}\text { Nervous } \\
\text { System }\end{array}$ & Muscular Symptoms \\
\hline $\begin{array}{l}\text { Pompe } \\
\text { Kimmelstiel }\end{array}$ & $\begin{array}{l}1932 \\
1933\end{array}$ & $\begin{array}{l}7 / 12 \\
5 / 52\end{array}$ & $\begin{array}{l}\text { Not enlarged } \\
\text { Greatly enlarged } \\
(1,600 \mathrm{~g} .)\end{array}$ & $\begin{array}{l}\text { Enlarged } 6 \times \\
\text { Frosted appear- } \\
\text { ance, vacuolate } \\
\text { muscle fibres }\end{array}$ & $\begin{array}{l}9 \cdot 39 \% \text { glycogen } \\
\text { Droplets of glycogen } \\
\text { under sarcolemma } \\
\text { Abundant glycogen } \\
\text { in lymph spaces }\end{array}$ & $\begin{array}{l}\text { Glycogen in } \\
\text { nerve cells }\end{array}$ & - \\
\hline Humphreys and Kato & 1934 & $5 / 12$ & $\begin{array}{l}\text { Enlarged, hepatic } \\
\text { cells, pale foamy } \\
\text { cytoplasm }\end{array}$ & $\begin{array}{l}\text { Enlarged } 5 \times \\
\text { Hypertrophy and } \\
\text { vacuolation of } \\
\text { muscle fibres }\end{array}$ & $\begin{array}{l}\text { Vacuolated muscle } \\
\text { fibres }\end{array}$ & - & - \\
\hline Wolff & 1936 & $5 / 12$ & Enlarged & $\begin{array}{l}\text { Left ventricular } \\
\text { wall } 1.4 \mathrm{~cm} \text {. } \\
\text { thick }\end{array}$ & $\begin{array}{l}\text { Vacuolated muscle } \\
\text { fibres in tongue } \\
\text { Skeletal muscle not } \\
\text { examined } \\
35.3 \% \text { of dry wt. } \\
\text { glycogen }\end{array}$ & - & $\begin{array}{l}\text { Poorly developed } \\
\text { muscles }\end{array}$ \\
\hline Hertz and Jeckeln & 1936 & $5 / 52$ & $\begin{array}{l}\text { Upper border of } \\
\text { normal weight }\end{array}$ & $\begin{array}{l}\text { Enlarged } 2 \times \\
\text { Large amounts } \\
\text { of glycogen in } \\
\text { muscle fibres } \\
\text { (vacuoles in } \\
\text { formalin-fixed } \\
\text { tissues) }\end{array}$ & $\begin{array}{l}\text { Round cell foci, } \\
\text { vacuolated muscle } \\
\text { fibres }\end{array}$ & - & Picture of cretinism \\
\hline Günther & 1939 & $11 / 12$ & $\begin{array}{l}\text { Enlarged ( } 325 \text { g.) } \\
\text { Vacuolated paren- } \\
\text { chymal cells }\end{array}$ & $\begin{array}{l}\text { Enlarged (75 g.) } \\
\text { Vacuolated } \\
\text { muscle fibres }\end{array}$ & $\begin{array}{l}\text { Vacuolated, haema- } \\
\text { toxylin and eosin, } \\
\text { blue-stained granules } \\
\text { in muscle fibres }\end{array}$ & - & $\begin{array}{l}\text { Paralysis and } \\
\text { atonia }\end{array}$ \\
\hline Antopol et al. & 1940 & $15 \mathrm{yr}$. & $\begin{array}{l}\text { Large }(1,850 \mathrm{~g} .) \\
\text { Parenchymal cells, } \\
\text { foamy cytoplasm }\end{array}$ & $\begin{array}{l}\text { Enlarged } 3 \times \\
\text { Vacuolated mus- } \\
\text { cle fibres, baso- } \\
\text { philic substance }\end{array}$ & $\begin{array}{l}\text { Basophilic masses in } \\
\text { centre of muscle } \\
\text { fibres staining posi- } \\
\text { tively with Best's } \\
\text { carmine stain }\end{array}$ & - & - \\
\hline Clement and Godman & 1950 & $6 / 12$ & $\begin{array}{l}\text { Enlarged, vacuola- } \\
\text { tion, glycogen in } \\
\text { liver cells }\end{array}$ & $\begin{array}{l}\text { Enlarged } 3 \times \\
\text { Glycogen in } \\
\text { muscle fibres, } \\
\text { vacuolation }\end{array}$ & $\begin{array}{l}\text { Vacuolation, baso- } \\
\text { philic substance }\end{array}$ & $\begin{array}{l}\text { Nerve cells } \\
\text { contain } \\
\text { glycogen }\end{array}$ & $\begin{array}{l}\text { Resembled cretin- } \\
\text { ism, mongolism, } \\
\text { and finally amyo- } \\
\text { tonia congenita }\end{array}$ \\
\hline \multirow[t]{2}{*}{ Childs et al. } & $\begin{array}{c}1952 \\
(1)\end{array}$ & $11 / 12$ & $\begin{array}{l}\text { Enlarged, liver cells } \\
\text { vacuolated, glyco- } \\
\text { gen in vacuoles }\end{array}$ & $\begin{array}{l}\text { Enlarged } 3 \times \\
\text { Perinuclear } \\
\text { clear spaces con- } \\
\text { taining eosino- } \\
\text { phil material, } \\
\text { glycogen in sar- } \\
\text { coplasm }\end{array}$ & $\begin{array}{l}\text { Granular or fibrillar } \\
\text { eosinophilic or baso- } \\
\text { philic material in } \\
\text { muscle fibres }\end{array}$ & $\begin{array}{l}\text { Glycogen in } \\
\text { nerve cells }\end{array}$ & Atonia, areflexia \\
\hline & (2) & $17 / 12$ & $\begin{array}{l}\text { Half normal size } \\
\text { (as Case 1) }\end{array}$ & $\begin{array}{l}\text { Enlarged } 4 \\
\text { (as Case 1) }\end{array}$ & $\begin{array}{l}\text { As Case } 1 \text { but less } \\
\text { basophilic material }\end{array}$ & $\begin{array}{l}\text { Glycogen in } \\
\text { nerve cells }\end{array}$ & $\begin{array}{l}\text { Weak, atonia, } \\
\text { areflexia }\end{array}$ \\
\hline Krivit et al. & $\begin{array}{c}1953 \\
(1)\end{array}$ & $19 / 12$ & $\begin{array}{l}\text { Enlarged, foamy } \\
\text { parenchymal cells }\end{array}$ & $\begin{array}{l}\text { Enlarged, vacuo- } \\
\text { lation of muscle } \\
\text { fibres }\end{array}$ & $\begin{array}{l}\text { Vacuolation, fine } \\
\text { granules and amor- } \\
\text { phous solid masses } \\
\text { staining strongly with } \\
\text { P.A.S. and Best's } \\
\text { stain material }\end{array}$ & - & $\begin{array}{l}\text { Retarded motor } \\
\text { development, } \\
\text { marked hyptonia, } \\
\text { reduced muscle } \\
\text { bulk }\end{array}$ \\
\hline \multirow[t]{3}{*}{ Zellweger } & $\begin{array}{c}1956 \\
(1)\end{array}$ & $310 / 12$ & Enlarged as Case 1 & $\begin{array}{l}\text { Enlarged } 3 \times \text { as } \\
\text { Case } 1\end{array}$ & $\begin{array}{l}\text { Biopsy, no histology } \\
\text { but glycogen content } \\
20 \times \text { normal }\end{array}$ & - & $\begin{array}{l}\text { Motor retardation, } \\
\text { hyptonia, hypore- } \\
\text { flexia, muscles soft } \\
\text { and reduced in bulk } \\
\text { Weakness, absent } \\
\text { reflexes, atrophy }\end{array}$ \\
\hline & (2) & $5 / 12$ & - & - & $\begin{array}{l}\text { No histology but } \\
\text { glycogen content } \\
13 \times \text { normal }\end{array}$ & 一 & $\begin{array}{l}\text { Weakness, promi- } \\
\text { nent muscles }\end{array}$ \\
\hline & (3) & $18 / 12$ & - & - & $\begin{array}{l}\text { Vacuolated muscles } \\
\text { fibres with basophilic } \\
\text { substance }\end{array}$ & 一 & $\begin{array}{l}\text { Weakness and } \\
\text { hypotonia }\end{array}$ \\
\hline Schnabel & 1958 & $5 \frac{1}{2} / 12$ & Enlarged (275 g.) & $\begin{array}{l}\text { Enlarged } 4 \times \\
\text { Vacuolated mus- } \\
\text { cle fibres }\end{array}$ & $\begin{array}{l}\text { Vacuolated muscle } \\
\text { fibres and basophilic } \\
\text { substance }\end{array}$ & $\begin{array}{l}\text { Nerve cell } \\
\text { contains } \\
\text { glycogen }\end{array}$ & $\begin{array}{l}\text { Scarcely any active } \\
\text { movement }\end{array}$ \\
\hline
\end{tabular}

Tuberculosis was suspected, but not confirmed. She lost a good deal of weight after this respiratory illness. In 1957, she had another respiratory infection with a slight haemoptysis and tuberculosis was again suspected from the radiological appearances of the chest. In March, 1958, she had a right-sided pleurisy and was referred to one of us by Dr. T. M. Curran who had noticed her muscular weakness and wasting.

On examination she was very thin, with generalized muscular wasting, but this was most pronounced in the quadriceps of both sides, which were extremely weak. She could not rise from a chair without using her arms. There was also bilateral weakness of dorsiflexion of the ankles. The posterior part of the left deltoid was noticeably wasted and the erectores spinae were very weak.

Upper limbs. - There was bilateral weakness of abduction; tremor of outstretched hands; no fasciculation or fibrillary twitching; no sensory disturbance, supinator, biceps, and triceps jerks present but very weak; abdominal reflexes present. 


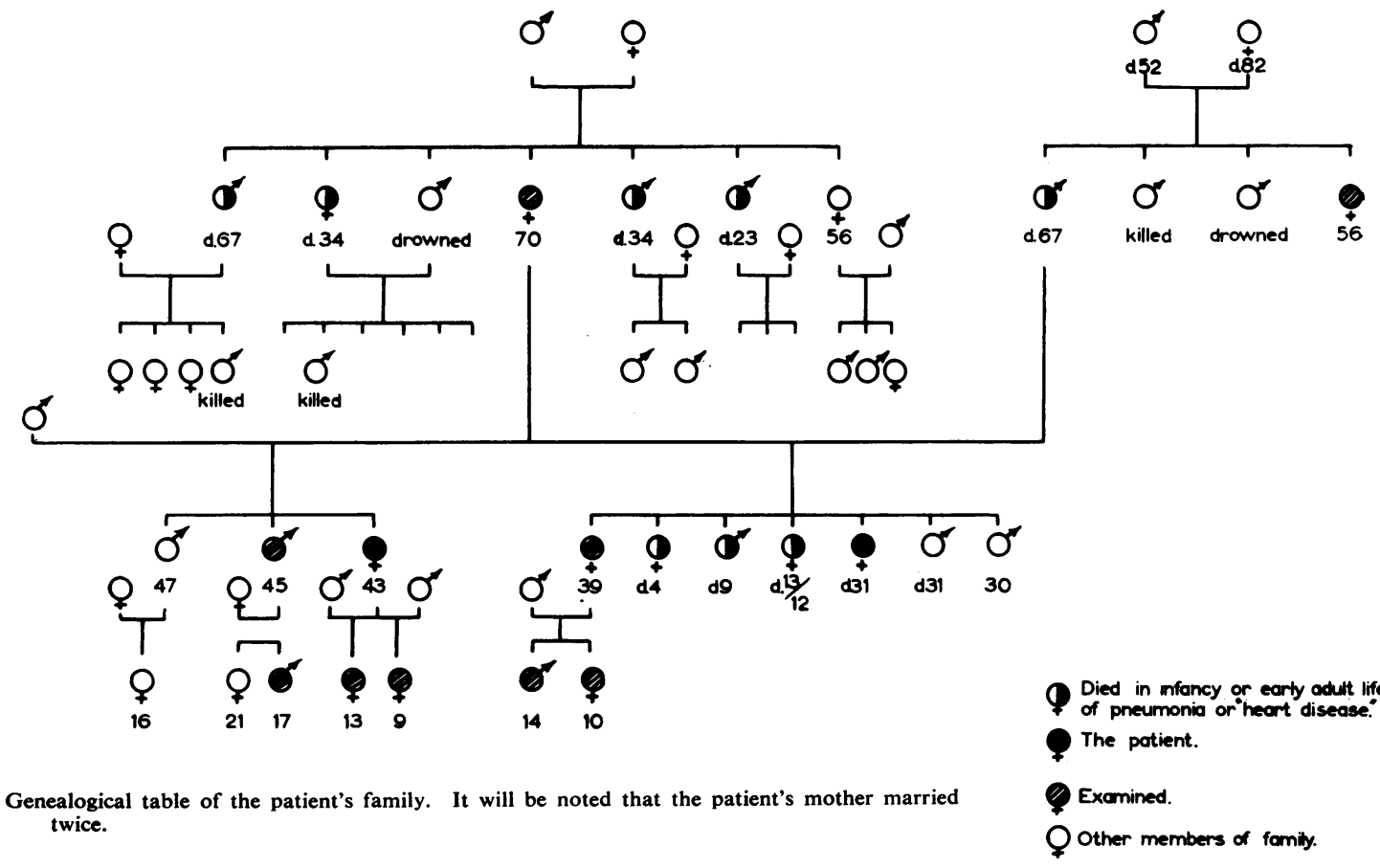

Lower Limbs.-There was gross weakness and wasting of both quadriceps; marked weakness of dorsiflexion of ankles; adduction of thighs weak; knee jerks and adductor jerks absent; ankle jerks just present; plantar responses flexor; no sensory disturbances in legs; no muscular tenderness or oedema.

Chest.-Slight dry cough, considerable dyspnoea on exertion, and a few basal rales and rhonchi.

Pulse rate was 68 per minute and very irregular due to extrasystoles, which were confirmed by an E.C.G. showing ectopic beats from various origins. Blood pressure was $120 / 75 \mathrm{~mm}$. $\mathrm{Hg}$. There was no oedema or evidence of congestive heart failure. Urine was normal. The liver was not palpable.

Investigations and Progress.- Strength duration curves from the right palmaris longus and the peroneus longus were within normal limits. Electromyography on the right palmaris longus showed a reduced interference pattern with long-duration polyphasic potentials of rather high voltage. The right peroneus longus also showed a reduced interference pattern especially on fatigue. These findings suggested a denervation which it was thought might be secondary to chronic myositis. There was no improvement in the muscular weakness after giving $10 \mathrm{mg}$. of tensilon intravenously. There was no resistance to decamethonium $(\mathrm{C10})$, respiratory embarrassment developing after $1 \frac{1}{2} \mathrm{mg}$. intravenously.

A blood count was normal. The E.S.R. was $10 \mathrm{~mm}$., the Wassermann reaction was negative. The cerebrospinal fluid was slightly contaminated by red cells, but otherwise normal.
Muscle biopsies were performed on the right palmari\& longus and vastus internus on April 11, 1958. Bothe muscles appeared normal and had a well-defined moton point. With haematoxylin and eosin staining the specio men from the palmaris longus appeared entirely normal The specimen from the vastus internus showed a moderate to severe degree of atrophy of scattered muscle fibres. About one-tenth of the muscle fibres showed a basophilic material which occupied the centre of the fibre and assumed either a spiral form or appeared as numerous smoothly contoured but irregularly shaped flakes which might be more or less fused together (Fig. 1). In the broader fibres this material occupied only the centre, being sharply separated from the myofibrils which appeared entirely normal. In the more slender muscle fibres the myofibrils had completely disappeared, the basophil material occupying the entire sarcolemmal sheath. The material did not fluoresce in ultra-violet light after staining with acridine orange by Armstrong's technique (Armstrong, 1956). Vital staining with methylene blue showed an excess of branching within the terminal intramuscular nerve bundles together with examples of collateral reinnervation and formation of multiple end plates on single muscle fibres. There were also axonal tangles on the surface of the muscle fibres of the type called neurocladism by Coërs (1955). Radiographs of the soft tissues showed no calcification in muscles. The basophilic material in the muscle fibres was at first thought to be parasitic in origin and to resemble the intramuscular cysts of sarcosporidiosis (Fig. 2b). However, the dye test and complement-fixation test for sarcosporidia and toxoplasma were negative. 
A course of daraprim, sulphadiazine, and cortisone had no effect on the muscular weakness and produced a moderate degree of anaemia.

The patient had left hospital when the nature of the material in the muscle fibres was determined and before she could be admitted again she died suddenly after developing influenza two days before. It seems probable, in view of the necropsy findings, that the cause of death was a sudden failure of the myocardium which was heavily infiltrated with polysaccharide.

No muscular weakness or wasting is known to have occurred in any members of the family, but as can be seen from the genealogical table there are a number of deaths at an early age from conditions vaguely referred to as pneumonia and heart disease.

Ten members of the family were examined but no myopathy was detected. The patient's mother is aged 70 and has auricular fibrillation and ischaemic heart disease, but no other member of the family examined had heart disease.

The blood glycogen level in the patient's mother, the son aged 43 by her first and the surviving daughter by her second marriage, were $6.1 \mathrm{mg}$., $5.4 \mathrm{mg}$., and $14.6 \mathrm{mg}$. respectively, i.e., within the limits of normal. No glucose6-phosphate was found in the blood from the mother as would be expected if there was a deficiency in glucose-6phosphatase.

\section{Post-mortem Examination}

Post-mortem examination performed at Hammerwich Cottage Hospital showed the body to be that of a wellnourished, lightly built young woman with scars of biopsies over both vastus internus muscles and the right palmaris longus. The brain was removed and fixed undissected. The trunk muscles and some proximal limb muscles showed a patchy pallor which was most marked in the rectus abdominis. The oblique abdominal muscles, and especially the quadriceps on the left side, showed practically no recognizable muscle tissue. The pectoralis major on both sides showed patchy areas where it had an appearance similar to that of smoked salmon, and some fasciculi were quite transparent. The lungs showed light pleural adhesions and were fixed undissected. The heart appeared normal, but the muscle, especially in the interventricular septum, was rather lighter than usual. The liver showed marked pallor. The spleen was normal. The kidneys were congested. There were some small haemorrhagic para-aortic lumph nodes. The suprarenals were normal. A piece of lung was taken and smears stained by Gram's and Ziehl-Neelsen's methods. Aerobic and anaerobic cultures were set up on blood agar and on Sabourand's and Loewenstein's media.

A mouse was injected intraperitoneally with a saline homogenate of the lungs, and a guinea-pig with material treated by the antiformin method. No organisms were seen in the smears and the cultures all remained sterile.

Dissection of Lungs after Fixation.-The right lung was much more severely affected than the left. The right lower lobe showed small white foci up to $3 \mathrm{~cm}$. in diameter surrounded by a red hyperaemic margin. This lesion had the appearance of the acinous-nodose lesions of tuberculosis and extended to the diaphragmatic and lateral pleura. Surrounding and spreading to the medial aspect of the right lower lobe were areas up to $3 \mathrm{~cm}$. in diameter where the cut surface of the lung presented a homogeneous grey, ground-glass appearance. The upper lobe on the right side presented a smaller number of whitish, irregularly-shaped foci, measuring up to $0.5 \mathrm{~cm}$. in diameter, and situated just above the interlobar fissure which was completely occluded by fibrous tissue. The left lung showed only a few such foci but there was a rectangular area $1 \mathrm{~cm}$. in diameter in the upper part of the lower lobe which had the appearance of an anthracotic scar and contained three pin-head-sized circular chalky foci, possibly with completely calcified centres.

\section{Histology}

Oesophagus.-Part of the epithelial lining was desquamated, but no abnormality was found in muscle.

Thyroid.-Great irregularity was seen in the size of acini, most of which contained colloid which in some acini had retracted away from the epithelium. This consisted mostly of a single layer of cuboidal cells, which had sometimes been shed into the lumen where they mingled with the colloid and on occasion occupied the entire acinar lumen. There was probably an increase in the interstitial fibrous tissue but this was nowhere more than slight.

Spleen.-The pulp was extremely congested with marked erythrophagocytosis. The Malpighian corpuscles were small and composed of lymphocytes.

Lungs.-In the areas which on cross-section had a smooth gelatinous appearance (right lower lobe), many alveoli were filled with serous material containing in some areas large numbers of pyknotic nuclei probably derived from leucocytes and histiocytes. In some areas the alveolar exudate appeared to be undergoing organization into fibrous tissue. In other parts of this lobe there were epitheloid cell tubercles with Langhans' type giant cells and with a small number of lymphocytes at their periphery. These tubercles did not show caseation but occasionally presented as islands of tissue surrounded by large areas of oedema. The whitish lesions in the right upper lobe were encapsulated foci of caseation. There was little P.A.S.-positive material apart from the central portions of the cytoplasm of the Langhans' giant cells.

Cutaneous Nerve.-A cutaneous nerve, probably the ulnar, did not show any abnormality.

\section{Uterus.-No abnormality was seen.}

Heart Muscle.-Apart from small areas of interstitial fibrosis where there appeared to be some loss and atrophy of muscle fibres, the only changes were in the muscle fibres themselves. The most striking abnormality were the large numbers of muscle fibres containing a homogeneous basophil material (Fig. 3) which almost invariably occupied only the central part of the fibre so that a rim of entirely normal looking myofibrils remained. 


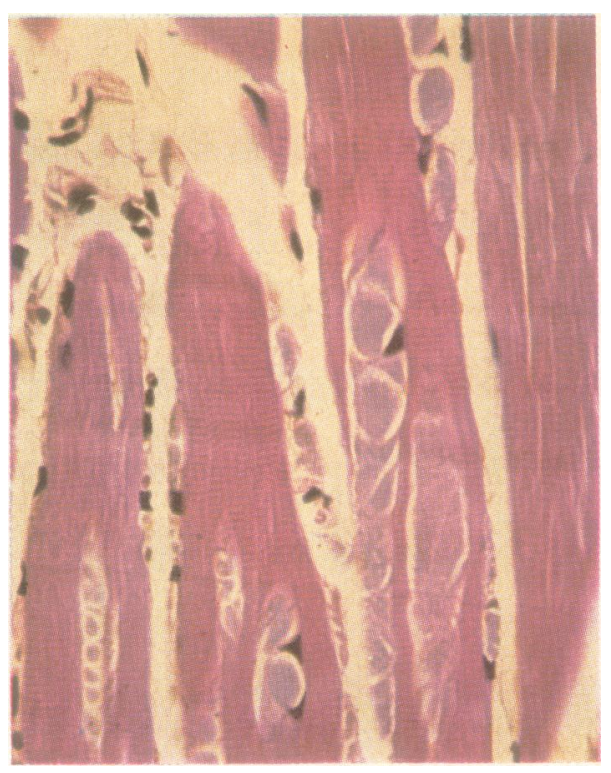

Fig. 1.-Biopsy specimen from the right vastus internus. Amorphous basophil material, surrounded by norma looking myofibrils, occupies the centre of several muscle fibres. One muscle fibre shows three subsarcolemmal deposits of the material. Haematoxylin and eosin $\times 400$.

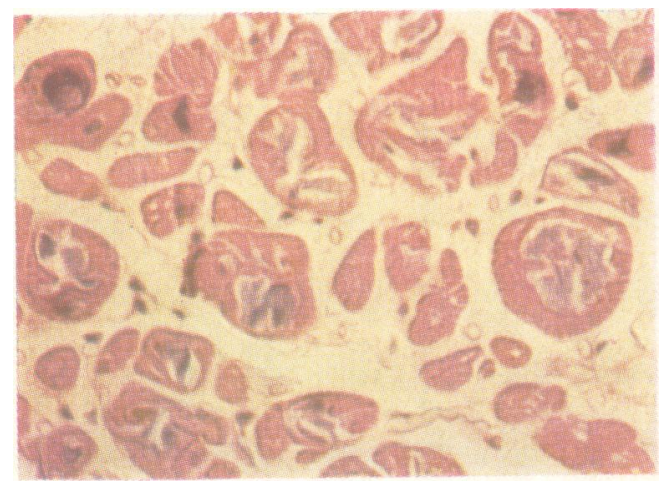

FIG. 3.-This and remaining illustrations are of post-mortem specimens. Heart muscle. Almost all the muscle fibres contain amorphous basophil material. Haematoxylin and eosin $\times 500$.

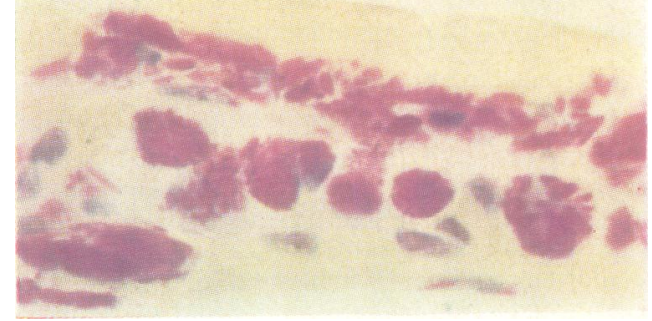

FIG. 5.-Pectoralis major: the basophil material is strongly P.A.S. positive. Periodic-acid-Schiff $\times 500$.

FIG. 6-Pectoralis major: most of the basophil material is brilliantly scarlet, but some of the free-lying material stains largely with the haematoxylin counterstain. Best's carmine stain $\times 440$.

FIG. $2(a)$-Post-mortem specimen from right pectoralis major. The amorphous basophil material is granular-floccular and occupies the centre of the muscle fibre. The adjacent myofibrils appear normal. Haematoxylin and eosin $\times 220$.

(b) Muscle fibres from a case of sarcosporidiosis, for comparison with $2(a)$. Haematoxylin and eosin $\times 110$.

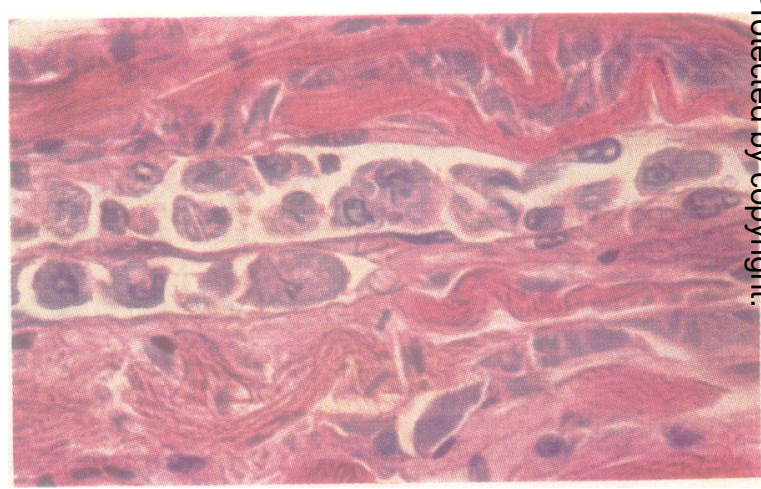

FIG. 4.-Pectoralis major: in this section the basophil material is both $\mathbb{D}$ free within the muscle fibre and also within histiocytes, although these are still enclosed by sarcolemma. Haematoxylin and eosin $\times 500$.

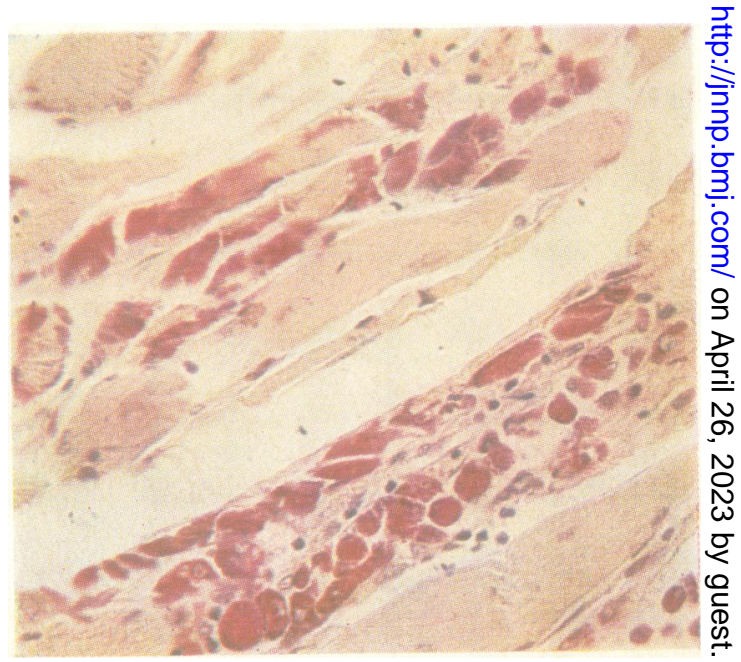


'IG. 7

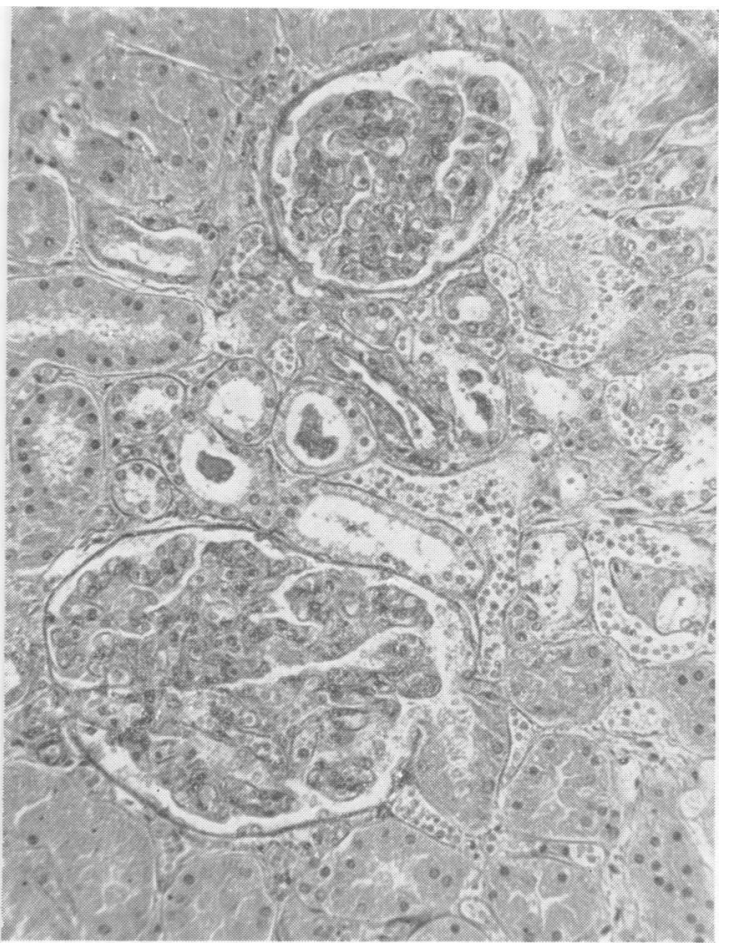

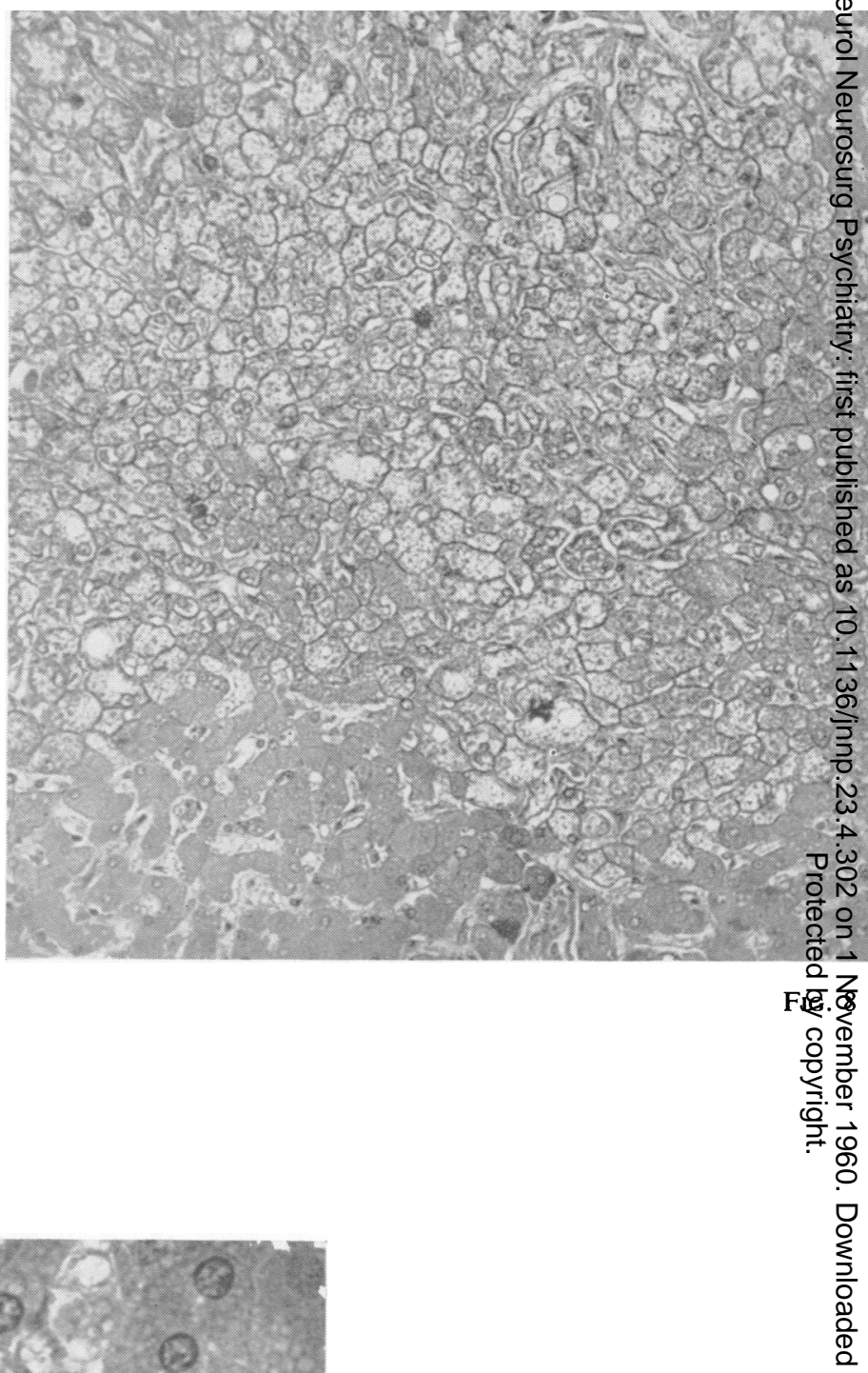

FIG. 7--Kidney: P.A.S.-positive material infiltrates the basement membrane of the $O$ glomeruli and convoluted tubules and is present in the lumen of the latter. This material stains blue in haematoxylin and eosin preparations. Periodic-acid-Schiff, 240.

FIG. 8.-Liver: large areas show vacuolation of the parenchymal cells. Periodic-acid- $\delta$ Schiff $\times 160$.

FIG. 9.-Liver: vacuolated parenchymal cells containing fine basophil granules, together with less severely affected cells containing finely vacuolar basophil 음 material almost but not completely filling the cell and closely resembling that seen in Harriman and Millar's cases of familial myoclonic epilepsy. Haematoxylin and eosin $\times 750$. 
TABLE II

APPEARANCE OF BASOPHIL MATERIAL

\begin{tabular}{|c|c|c|c|}
\hline Stain or Test & Heart Muscle & Skeletal Muscle & Remarks \\
\hline $\begin{array}{l}\text { Haematoxylin and eosin } \\
\text { Schiff without periodic acid } \\
\text { Periodic-acid-Schiff with acetylation } \\
\text { Periodic-acid-Schiff } \\
\text { Diastase } \\
\text { Toluidine blue }\end{array}$ & $\begin{array}{l}\text { Mauve to blue } \\
\text { Very pale mauve } \\
\text { Slightly more intense pink } \\
\text { Intense scarlet magenta }+++ \\
\text { Totally resistant } \\
\text { Not metachromatic }\end{array}$ & $\begin{array}{l}\text { Mauve to blue } \\
\text { Colourless } \\
\text { Colourless } \\
\text { Intense scarlet magenta }+++ \\
\text { Totally resistant } \\
\text { Not metachromatic }\end{array}$ & $\begin{array}{l}\text { Not free aldehyde } \\
1: 2 \text { glycol grouping } \\
\text { Carbohydrate } \\
\text { Not normal glycogen } \\
\text { Not acid mucopolysaccharide or } \\
\text { hyaluronic acid or chondroitin } \\
\text { sulphuric acid }\end{array}$ \\
\hline Alcian blue & Very pale blue & Colourless & $\begin{array}{l}\text { Not acid mucopolysaccharide or } \\
\text { hyaluronic acid, could be } \\
\text { mucoprotein or neutral muco- } \\
\text { polysaccharide }\end{array}$ \\
\hline $\begin{array}{l}\text { Millon's reagent } \\
\text { Sudan black B } \\
\text { Best's carmine stain }\end{array}$ & $\begin{array}{l}\text { Negative } \\
\text { Colourless } \\
\text { Brilliant maroon, strongly } \\
\text { positive }\end{array}$ & $\begin{array}{l}\text { Colourless - } \\
\text { Scarlet but not so intensely } \\
\text { staining as in cardiac muscle, } \\
\text { sometimes only stained with } \\
\text { haematoxylin counterstain }\end{array}$ & $\begin{array}{l}\text { Not lipoprotein or mucoprotein } \\
\text { Not lipoprotein } \\
\text { Glycogen-like substance }\end{array}$ \\
\hline
\end{tabular}

The material had a quite irregular outline and usually stained a pale greyish blue with haematoxylin and eosin, though occasionally it stained more intensely and had a purple tinge. Within some muscle fibres the material was in the form of a single mass, but most commonly it was broken up into "flakes". Many of the muscle fibres contained lupofuscin and this was also present in some of the fibres containing basophil material, but the appearances did not suggest that the lipofuscin was a precursor of the basophil material. The staining reactions of the latter are given in Table II and suggest that it is a neutral mucopolysaccharide.

The high incidence of the degeneration was indicated by the ease with which high-power fields could be found in which more than a third of the muscle fibres contained basophil material (see discussion).

Skeletal Muscle.-There was marked inequality in the size of the muscle fibres of the right pectoralis major, extremely slender muscle fibres being intermingled with less atrophic and normal sized fibres. Fibrous tissue was only slightly increased and was only at all marked where muscle fibres had completely disappeared. The surviving muscle fibres showed infiltration with the same sort of basophil material as was seen in the muscle biopsies (Fig. 4). It was present in the intrafusal as well as the extrafusal muscle fibres and stained brilliantly magenta with the periodic-acid-Schiff technique (Fig. 5). By this method it was particularly easy to pick out columns of histiocytes distended with mucopolysaccharide material which in haematoxylin-and-eosin-stained sections resembled closely the histiocytes seen in myositis. In myositis, however, the basophil material (probably ribose nucleic acid) does not give a positive reaction with P.A.S. staining and fluoresces red with acridine orange on fluorescent microscopy, while in this case the contents of the histiocytes, as well as most of the free-lying material in the muscle fibres, did not fluoresce at all. There was, however, a fine stippling of some of the nonfluorescing " basophil " material with particles fluorescing red. With Best's carmine stain, most of the material both lying free in the muscle fibres and within the histiocytes stained red but not as intensely as in the muscle fibres of the heart. It appeared more finely granular than in P.A.S. preparations. Some of the more flaky material lying free in the muscle fibres stained pale blue in preparations stained with Best's carmine and counterstained with haematoxylin.

The peroneus brevis, which was cut transversely, showed no abnormality apart from the presence in about one-third of the muscle fibres of basophil material, mostly in the centre of the muscle fibres but occasionally under the sarcolemma.

The greater part of the left vastus internus had been converted into adipose tissue in which were scattered small fasciculi containing muscle fibres showing varying degrees of atrophy, each being surrounded by fibrous tissue.

Kidney.-The most striking features were the basophil staining of the basement membrane of some of the glomeruli and convoluted tubules and the presence of amorphous basophil material in the lumen of some of the convoluted tubules (Fig. 7). The basement membrane was not definitely thickened but appeared more prominent than normally because of its abnormal staining. The basophil material was Schiff-positive.

Liver.-In paraffin sections groups of cells not clearly related to any part of the lobule showed a remarkable vacuolation leaving them deprived of all contents apart from a few fine, pale pink, floccular granules; at the same time the cell membrane was strikingly well preserved and showed a polygonal outline quite unlike the circular outline of the vacuoles in fatty infiltration of the liver (Fig. 8). The nuclei of the affected cells had either a normal appearance or were hypochromatic. Other cells showed a less complete fine soap-bubble vacuolation. The affected area, which usually did not quite fill the whole cell, stained slightly basophil as compared with the peripheral rim of normal looking cytoplasm (Fig. 9). This appeared to be an earlier stage of the complete vacuolar degeneration referred to above. With periodicacid-Schiff staining this basophilic material stained brilliant scarlet-magenta. It is probable that a high proportion of this material was glycogen as it was indeed 
digested by diastase. However, the granules in the vacuolated cells were P.A.S. positive and also diastase resistant. They may therefore be considered pathological and are probably closely related to the basophil material in the muscle fibres of the heart.

\section{Discussion}

The findings in this case differ from most cases of cardiomuscular glycogenosis described previously in the absence of vacuolation in the heart and skeletal muscle fibres. That this may be related to the age of the patient is suggested by the similar appearances in the heart muscle of the first patient (aged 15 years) reported by Antopol and his coauthors. The nature of the basophilic material present in the cardiac and skeletal muscle fibres is obscure. It differs more strikingly from glycogen than the substance deposited in the liver cells in being resistant to autolysis, water, and the action of diastase. Our histochemical findings suggest that it is a neutral mucopolysaccharide, but Schnabel, who made a very detailed histochemical study of the material in his infantile case, agreed with Dark (Zellweger, et al., 1955) that the basophilic material in their case was free acid mucopolysaccharide since, unlike the material in our case, it showed strong metachromasia with toluidine blue. The variation in intensity of staining with Best's carmine stain in the skeletal muscles suggests that the composition of the material is not the same in all tissues or even in the same tissue. The apparent differences in solubility or resistance to autolysis of the material infiltrating the liver cells and the cardiac muscle fibres leads to the same conclusion.

A similar material is encountered in the heart muscle in increasing age, thyroid deficiency, and the familial myoclonic epilepsy of Unverricht.

Basophilic Degeneration of Myocardium with Increasing Age.-The occurrence of this material in heart muscle appears to have been reported first by Hewitt (1910) in two cases in which no other evidence of myocardial disease was present. Haumeder (1935), in an extensive study of 320 cases, found some fibres with basophilic degeneration in nearly a third of the cases. Ninety-five per cent of the patients whose hearts showed this change were in the 40-80 year age group. Liebegott (1937) also found basophilic degeneration in $42 \%$ of 50 hearts. Umeda (1940) found this degeneration in 60 out of 83 hearts examined with Patzelt's stain and in $80.7 \%$ of 145 cases using Bauer's stain and suggested the term "mucoid degeneration of the heart". Spencer (1950) was also impressed by the increased incidence of the degeneration in the higher age groups, all except four out of 30 cases being over the age of 50. He thought that the condition was probably akin to the mucoid degeneration known to occur in the media of the aorta and large arteries. Shiozawa in two recent studies (1958) of 300 unselected necropsies found "mucopolysaccharide degeneration " in $85 \%$. No correlation was observed between mucopolysaccharide degeneration and specific or cardiac diseases. He also noticed an increasing incidence with advancing age, the incidence being $96.4 \%$ in the third decade. It must be stressed that in all these series there was no mention of the number of muscle fibres affected and it is unlikely that the amount of basophilic material present ever approached that seen in our case.

Basophilic Degeneration of Myocardium and Myxoedema.-Deposits of a basophilic material in the heart muscle in cases of polyglandular dysfunction and myxoedema have been reported by Dietrich (1941), Doerr and Holldack (1948), and Brewer (1951). Doerr and Holldack considered its presence a specific myxoedematous change, but in view of the facts mentioned in the preceding paragraph, some statistical data were clearly needed. These were provided by Fisher and Mulligan (1943) who devised a basophilic degeneration index, viz., the number of muscle fibres showing this degeneration in an area of $10.28 \mathrm{sq}$. mm. of a $6 \mu$ thick section. In 11 cases without myxoedema showing the most fibres with basophilic degeneration out of a control series of 67 cases without disease of the thyroid, the average basophilic degeneration index was only 7.7. In eight cases with atrophy of the thyroid gland the index was $40 \cdot 5$. It is clear, therefore, that myxoedema increases the tendency to this form of degeneration.

In our case we studied in a P.A.S.-stained section two areas: (1) a relatively lightly affected area of 16.32 sq. mm., which yielded 263 muscle fibres with basophilic degeneration, and (2) a more severely affected area of 4.08 sq. mm. which contained 703 degenerated muscle fibres. Thus there were 966 basophilically degenerated muscle fibres in an area of 20.4 sq. mm. giving a basophilic degeneration index of approximately 950 , i.e., far in excess of what occurs in myxoedema. In any case, our patient showed no clinical evidence of myxoedema and the thyroid gland was histologically normal.

It is certain, therefore, that the mucopolysaccharide deposition in the cardiac muscle fibres in the cardiomegalic form of glycogen storage disease, as exemplified by our case, greatly exceeds that seen in even the most severely affected myxoedematous heart. The fact that the basophilic substance is indistinguishable in myxoedema from that seen in cardiomegalic glycogenosis is not necessarily to be 
interpreted as indicating a similar metabolic disorder in the two conditions bit merely the inadequacy of current histochemical techniques to distinguish between different polysaccharides. The need to differentiate between thyroid deficiency and neuromuscular glycogenosis is of more than sciertific interest, as the infant suffering from the latter condition may present a clinical picture closely resembling that of cretinism, especially as swelling of the tongue is common to both conditions. In this connexion, three cases of " cretinism" in which a basophilic material was found in the skeletal muscle fibres (Marchand, 1906; Schultz, 1921) arouse the suspicion that they may really have been cases of glycogenosis although there was said to have been histological evidence of thyroid atrophy. These are the only reports in the literature we have been able to find of basophilic degeneration of skeletal muscle in thyroid deficiency. It is unfortunate that Marchand's report was not illustrated and Schultz's insufficiently detailed to determine how closely the muscular changes resembled those seen in our cases.

Criteria for Diagnosis of Glycogen Storage Disease in Our Case.-From the above discussion it will be seen that deposition of basophilic material in the heart muscle and even skeletal muscle is not a sufficier.t basis for a diagnosis of glycogen storage disease. In support of this diagnosis in our case, it is, therefore, necessary to point out (1) that the amount of basophilic material in the heart muscle was greater than has ever been described in any condition other than glycogen storage disease; (2) that the liver showed the characteristic changes of glycogen storage disease (compare our Figs. 8 and 9 with Fig. 3 of Krivit and co-authors).

Basophilic Degeneration of Myocardium in Familial Myoclonic Epilepsy.-The changes in the heart muscle in our case closely resemble those seen in cases of familial myoclonic epilepsy by Harriman and Millar (1955). In this condition epilepsy followed by almost continuous jerkings develops at or about the time of puberty. In 11 of the 22 cases listed by Harriman and Millar the curious bodies known as Lafora bodies and believed to be composed of an acid mucopolysaccharide were diffusely present within the nerve cells of the central nervous system. It is of some interest, therefore, that the basophilic deposits in the heart and skeletal muscle in glycogenosis are also believed to be a mucopolysaccharide. More interesting, however, is the remarkable similarity between the changes in the heart muscle and liver in Harriman and Millar's cases and those seen in the case reported in this paper. It gives ground for suggesting that evidence of a disorder of glycogen metabolism should be looked for in future cases of familial myoclonic epilepsy. In view of the presence of a basophilic substance in the basement membrane of the glomeruli and in the lumen of the renal tubules in our case, we would also recommend rot only in cases of myoclonic epilepsy but also in obscure myopathies of adult life that the urine should be examined for the presence of mucopolysaccharides.

One last condition requires to be mentioned. This is the " myopathy due to a defect in muscle glycogen breakdown" described in 1951 by McArdle. In this condition there appears to be a failure of glycolysis so that glycogen is not broken down to pyruvic and lactic acid. Unfortunately, no biopsy was performed in McArdle's case and no biochemical studies in our own. However, in view of the fact that in McArdle's case one might anticipate an accumulation of glycogen in the muscles, it seems worth mentioning that the subsarcolemmal deposits of basophilic substance in the biopsy (Fig. 1) from our case have a certain similarity to the subsarcolemmal blebs recently reported in a muscle biopsy from a case of McArdle's myopathy by Schmid and Mahler (1959).

\section{Summary}

A case presenting as a cardio-skeletal myopathyo in adult life with features suggestive of glycogen storage disease was studied by muscle biopsy and at necropsy 10 years after the onset.

The histological findings resembled those seen in infantile cases of the cardio-skeletal muscular form of glycogen storage disease except that vacuolation was not present in the myocardium and affected skeletal muscles. The most striking feature was the infiltration of cardiac and skeletal muscle with a basophilic substance which appeared to be a neutral mucopolysaccharide. A similar material is found in the myocardium with increasing age and particularly in myxoedema, but in much smaller quantities.

The changes in the liver and heart muscle resembled those previously reported in familial myoclonic epilepsy. There was also histological evidence of excretion of a mucopolysaccharide, suggesting that such substances should be looked for during life in cases of the last-named condition as well as in obscure myopathies occurring in adult life.

We are indebted to Dr. H. T. Fawns (Worcester Royal Infirmary) for carrying out the biochemical estimations, and to Dr. R. A. Goodbody for Fig. $2 b$.

Our thanks are due to Mr. Derek Hayward for histological and to Mr. Gordon Gasser for photographic assistance. 


\section{REFERENCES}

Antopol, W., Boas, E. P., Levison, W., and Tuchman, L. R. (1940). Amer. Heart J., 20, 546.

Armstrong, J. A. (1956). Exp. Cell Res., 11, 640.

Brewer, D. B. (1951). J. Path. Bact., 63, 503.

Childs, A. W., Crosse, R. F., and Henderson, P. H. (1952). Pediatrics, $10,208$.

Clement, D. H., and Godman, G. C. (1950). J. Pediat., 36, 11

Coërs, C. (1955). Acta neurol. psychiat. belg., 55, 741.

Dietrich, W. (1941). Virchows Arch. path. Anat., 307, 566.

Doerr, W., and Holldack, K. (1948). Ihid., 315, 653. Fisher, C. E., and Mulligan, R. M. (1943). Arch. Path. (Chicago), 36,

Gierke, E. von (1929). Beitr. path. Anat., 82, 497.

Günther, R. (1939). Virchows Arch. path. Anat., 304, 87.

Harriman, D. G. F., and Millar, J. H. D. (1955), Brain, 78, 325.

Haumeder, M. E. (1935). Amer. J. Path. 11, 535.

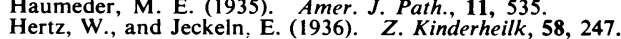

Hewitt, J. H. (1910). Bull. Johns Hopk. Hosp., 21, 279.

Humphreys, E. M., and Kato, K. (1934). Amer. J. Path., 10, 589.

Kimmelstiel, P. (1933). Beitr. path. Anat., 91, 1.

Krivit, W., Polglase, W. J., Gunn, F. D., and Tyler, F. H. (1953) Pediatrics 12, 165.

Liebegott, G. (1937). Beitr. path. Anat., 98, 410.

Marchand (1906). Münch. med. Wschr., 53, 1440.

McArdle, B. (1951). Clin. Sci., 10, 13.

Pompe, J. C. (1932). Ned. T. Geneesk., 76, 304.

(1933). Ann. Anat. path. med.-chir., 10, 23.

Schmid, R., and Mahler, R. (1959). J. clin. Invest., 38, 2044

Schnabel, R. (1958). Virchows Arch. path. Anat., 331, 287 and 536.

Schultz, A. (1921). Ibid., 232, 302.

Shiozawa, K. (1958). Shinshû med. J., 7, 162 and 184.

Spencer, H. (1950). J. Path. Bact., 62, 653.

Umeda, K (1940). Virchows Arch. 62, 653.

Wolf, K. (1936). Beitr. path. Anat., 97, 289.

Zellweger, H. (1956). Disch. med. Wschr., 81, 1907.

Zellweger, Dark, A., and Abu Haidar, G. A. (1955). Pediatrics., 15, 715. 